\title{
Study on Development Model of China's Online Rental Business
}

\author{
Shuxia Dong ${ }^{1, a}$, Yadan Luo ${ }^{2, b}$ Xiaoxuan zhang ${ }^{3, c}$ \\ ${ }^{1}$ School of E\&M,China University of Geosciences,Wuhan, 430074, P.R.China \\ aDongshuxia12345@126.com \\ b595296858@qq.com
}

Keywords: Sharing economy.online rental.development model.

Abstract. Guided by the Sharing economic mode, so many companies, at home and abroad, have already developed rapidly, such as Didi, Tujia, Airbnb, Uber and so on. Online rental industry is the outstanding representative of the Sharing economic development model.This paper aims to analysis both the development model and profit model on China's online rental business. It also aims to find out the prospects on China's online rental business.

\section{Introduction}

Online rental means that renters book the room on internet or on mobile internet, and pay part or all of the price to the owner online, online platform win the profit based on the rental commissions or advertising. There are many different kinds of house resources, such as apartment, holiday apartment and other personalized short-term accommodation products.

As the development on the internet and short-term rental market become maturing, as the representative in China, Tujia, Mayiall developed rapidly on online rental platform. The deal size in online rental market increase rapidly. In 2012, it started with 140million, and it reached to 800 million in 2013, until 2014 it was already up to 3.8billion, and now it will almost reach to 30 billion.

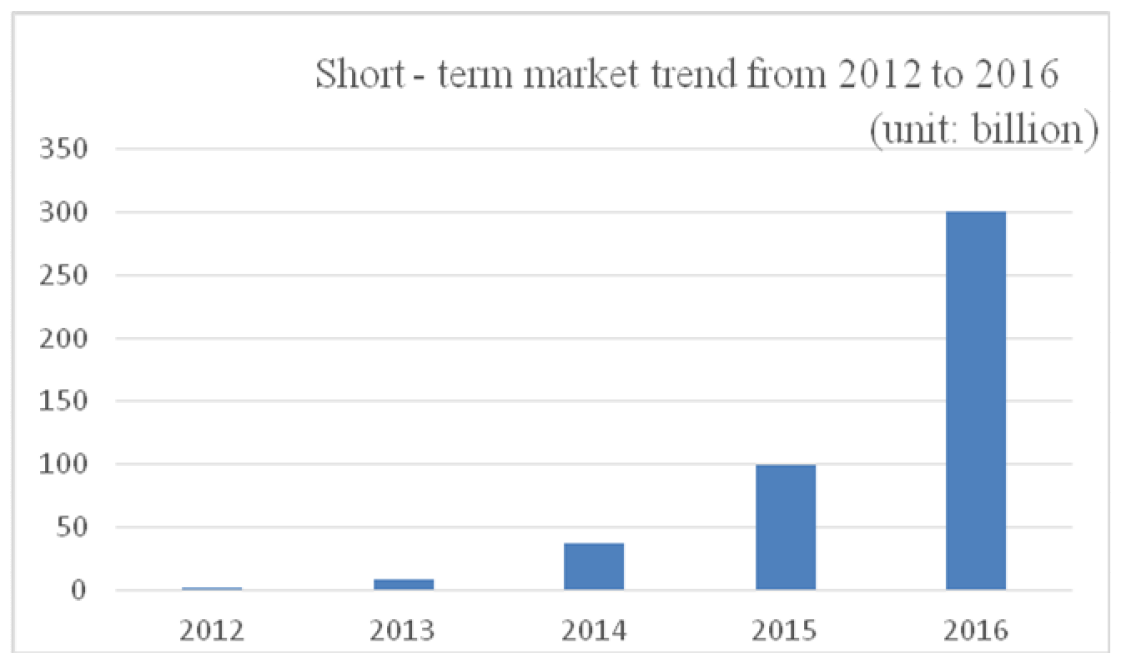

Figure 1-1

There are two business models on online rental business, B2C and $\mathrm{C} 2 \mathrm{C}$. The rental business will provide the house resources in $\mathrm{B} 2 \mathrm{~B}$, rental income will be divided by the rental company and the landlord proportionally, e.g. tujia. In $\mathrm{C} 2 \mathrm{C}$, the owner will provide the house, owner and the renter will make a deal on the rental platform, and the platform will get the profits from the owner and the advertisement, e.g. mayi.com.

\section{Development Status of domestic online rental business}

The domestic online rental businesses are all based on Airbnb. In China, started with airizu which was invested by Rocket Internet in 2011. However, it couldn't find a reasonable profit model, end in July 
2013. At the same time, tujia, mayi, youtx, xiaozhu were all opened online. Except from this, the specialized search engine, souduanzu, also appeared. Souduanzu was first search engine for the short-stay rental platform, it was supposed to be the 'qunaer' in short-term rental and daily rate.

The paper refers to analysis on Tujia, Xiaozhu and Zhubaijia,.

\section{www.tujia.com}

Overseas housing resources were online on December 5th, 2012. After 2 days, Tujia made a deal with Xiecheng. Until 2015, Tujia was covered on 288 destinations in China and 353 destinations abroad, and had 400,000 housing resources. Meanwhile, Tujia signed a cooperation agreement with nearly 200 government agencies and reached a strategic cooperation with most of the real estate development enterprise in domestic TOP 100. Tujia held 100 billion in assets under management and had more than 800,000 reserved housing resources. Tujia could be so succeed that all base on its well-known brand advantage, creative business model and mighty fine operation capability.

Tujia mainly provide booking online, Butler Real Estate Services and hosted services. Combined with the specific situation in Chinese, the Sweetome hotel management system is used to provide butler service to the real estate owners in different locations. At the same time, rent the house on www.tujia.com in spare time. Without wasting the daily use, maximize the realization of asset appreciation.

\section{www.xiaozhu.com}

As a typical representative of the Airbnb model in China, Xiaozhu is designed to build a green platform system for landlords and tenants with honest, secure online communication, based on the property, mechanisms, personal security and identity identification strategies. This system will make the landlord's spare resources fully utilized and maximized by sharing, while strengthening the social relationships and interactions between landlords and tenants, providing a more humane experience for the tenant than the traditional hotel. Human nature is the characteristics of piglet short rent, to provide cost-effective, family atmosphere, a humane accommodation choice.

In August 2012, Xiaozhu established cooperative strategic with 58, and developed rapidly. The Xiaozhu platform have nearly 70,000 sets of high-quality housing in the domestic 213 cities. Total number of houses in 2015 increased more than 350\% in 2014. More and more young people are beginning to experience the sharing of the economy, living in a stranger's home to experience a humane short rent, Xiaozhu platform has accumulated 3 million active users, turnover in 2015 rose by $500 \%$ in 2014.

\section{www.zhubaijia.com}

Zhubaijia is a short rental brands for both domestic tourists and overseas, through the sharing of economic mode, provide short-term rental housing services for the Chinese outbound free travel groups. Compared with the Airbnb, Zhubaijia is more familiar with the Chinese tourists, in addition to the provision of short housing services, but also provide All-weather call center customer service, itinerary planning, transfer machine, car rental, booking and tour guide and other travel services. Compared with other domestic online short term rental platforms, it is more focused on the settlement of the needs of Chinese tourists traveling abroad. All around the world, Zhubaijia has millions of sets of selected listings, covered Europe, North America, Oceania, Japan and South Korea, Thailand and other places more than 60 travel hotspot cities, housing resources including from ordinary apartments to special European-style castles.

Zhubaijia, expanded the scale of business rapidly in 2014 and 2015. The operating income was 659,000 in 2015, grow 68 times compared with last year,. Revenue growth at the same time, the profit also maintained a certain growth rate, the second half year of 2015 grow about 8.7 times. According the earnings in 2015 showed that the main business income of overseas accounted for $79 \%$ of total income. 


\section{Online rental business model}

The business model of the online short term rental business is mainly the $\mathrm{B} 2 \mathrm{C}$ and $\mathrm{C} 2 \mathrm{C}$. B2C, Business-to-Customer, the enterprise deal with customers on the internet. $\mathrm{C} 2 \mathrm{C}$, Customer to Customer, means customers deal with each other.

\section{Online short-term rental and sharing economy}

Online short-term rental enterprises provide on-line trading platform for landlords and tenants, while it also provide a variety of peripheral services. Cooperating with the independent operation of the offline team or the landlord, it will collect the various types of housing. On the platform, it will provide consumers with house searching and transaction guarantee services. Also there is a platform to use with the Housing Intermediary agency cooperation mode.

Short-term rental, is not only bringing a rent rental industry, tourism industry to a new area of development, but also promoted the development of relevant fields of economic theory at the theoretical level, such as, the sharing economy. The Sharing economy is also essentially a business model and also named as a "P2P" model. With the success of Airbnb, Uber and other companies, it attract the current attention and become a popular business model.

\section{Analysis on business model of online short-term rental enterprise}

\section{Business scope of the enterprise}

In order to enlarge the market share of the domestic online short term rental enterprises, this paper puts forward a proposal that the enterprise should have personalized service, and forms the differentiation competition among other online short rental enterprises. But also different from the online leasing enterprises, the provision of services are slightly different. As shown in table 2-1:

\begin{tabular}{|c|c|c|}
\hline $\begin{array}{l}\text { Online short-term } \\
\text { rental enterprise }\end{array}$ & Different business scope & $\begin{array}{l}\text { Same business } \\
\text { scope }\end{array}$ \\
\hline Tujia & $\begin{array}{l}\text { The more personalized holiday tourism services, such } \\
\text { as: pick-up, house cleaning, and provide butler service, } \\
\text { hosted service, the professional hotel management will } \\
\text { take care of the house. }\end{array}$ & \multirow{3}{*}{$\begin{array}{l}\text { The function of } \\
\text { short rental } \\
\text { information } \\
\text { display, } \\
\text { consultation, price } \\
\text { comparison, } \\
\text { online transaction, } \\
\text { tenant and } \\
\text { landlord } \\
\text { evaluation and } \\
\text { sharing through } \\
\text { computer or } \\
\text { mobile end. }\end{array}$} \\
\hline Xiaozhu & $\begin{array}{l}\text { Highlighting personalized short term rental service } \\
\text { experience, emphasizing the human-oriented in the } \\
\text { process of renting, paying attention to customer } \\
\text { experience, on the basis of leasing service behavior; } \\
\text { practice on the "Tenant protection scheme", "personal } \\
\text { Landlord property protection scheme". }\end{array}$ & \\
\hline Zhubaijia & $\begin{array}{l}\text { Focus on providing services for the Chinese who have } \\
\text { short rental needs in foreign countries, as well as local } \\
\text { tickets, attractions and other services. }\end{array}$ & \\
\hline
\end{tabular}

Table 1-1 Business scope of the enterprise

\section{The methods of realizing value of enterprises}

(1) Charge a commission on a transaction;

(2) Website advertising costs. Rely on the site's existing traffic resources, carry out a reasonable advertising position. Get the pay from promotion of tourism or housing advertising.

(3) Additional Service fee: Butler service, house cleaning service, pick-up service, etc.

(4) Third-party cooperation charges. such as insurance, scenic tickets, tour guides and other services embedded sales, according to the transaction conditions to collect some fees. 


\section{Analysis on the development of online short-term leasing enterprises in China}

\section{Opportunities and challenges coexist}

\section{The gradually growth on market demand}

With the popularity using on smart phones, more and more people are making use of mobile apps to book accommodation. The main force of the short renters are born in 1980 or 1990.

\section{The exploring on business models and profit models}

Short-term rental business happened since only five years ago, the business and profitability model is gradually exploring. There are many problems in the market acceptance degree and the housing management in China, which need to be strengthened in the credit system construction, meticulous service and so on.

\section{Opening up overseas markets}

The domestic short-term rental market develop rapidly, manufacturers are also actively expanding the short rental market overseas at the same time. For example, Zhubaijie currently has opened more than 60 popular destinations around the world short rental business online, has created a overseas short rental platform for Chinese tourists to have a dedicated service. Tujia launched overseas market expansion business. Youtx, Dayu and other companies are trying to do the overseas online short rental market.

\section{Promoting the Internet of tourism real estate industry}

In the development of the online short term rental market, it has been combined with the traditional tourism real estate industry, which has improved the industrial form of tourism real estate and promoted the Internet of tourism real estate. The main performance is to promote the vacation apartment can be operated, promote the sharing benefits of vacation villas, promote the birth and prosperity on vacation accommodation.

Domestic short rent market develop till now, basically laid the domestic short rent market initial market pattern. At present, there are two profit models on the domestic short-term rental market, one is information platform, the other is their own control of the full range of services. Although the former is more advantageous in the era of shared economy, and lower in the cost of investment, but latter must be the one to achieve the "replacement of the hotel".

\section{References}

[1] Fast-Path Research institute. 2017 online short-term rental market report[R], 2017

[2] Iresearch Consulting. 2016 China online holiday leasing market research Report.[R]2016

[3] Wang Bin, Lin Danming. The evolution and innovation of e-Business management model [j]. Journal of Shantou University, 2005.Vol.21. No. 4

[4] Ling Su, Zhang Zan. A study on the development path of "sharing economy" in China _ take online short rent as an example, [J]. Modern management Science-10th issue of the 2014 P36-38.

[5] Arain-Offer,,. Internet business model and strategy,Beijing, Tsinghua University Publishment,2002

[6] Pan, Zhang Cran. Shared economy: On-line short-term leasing business model [j]. Technology and business. No. 2014.03. P74-75

[7] Huale. Review of foreign business model theory [j]. Foreign economics and Management, 2010 (10). 